UDC 004.9: 519.81

\title{
V. BESKOROVAINYI
}

\section{PARAMETRIC SYNTHESIS OF MODELS FOR MULTICRITERIAL ESTIMATION OF TECHNOLOGICAL SYSTEMS}

The subject matter of the article is the problem of multicriteria estimation of the properties of technological systems (TS) in the process of their structural-parametric optimization. The goal of the study is to increase the efficiency of procedures for multicriteria estimation of TS properties at the stages of their design and reengineering using the technology of comparative parametric identification of the preferences of a decision maker. The objectives are: to increase the adequacy of the additive-multiplicative model of multifactor estimation of variants of building a TS based on the Kolmogorov-Gabor polynomial; to develop an efficient method of parametric synthesis of additive-multiplicative models of multifactor estimating and selecting variants of building a TS based on a decision maker's preferences; to carry out the analysis and give recommendations on the practical use of the suggested method of parametric synthesis of models of multicriteria TS estimation. The methods used are: system analysis, decision theory, identification theory, multicriteria optimization methods. The following results are obtained: to increase the adequacy of the models of TS multifactor estimation, it is suggested to use the utility function of partial criteria that makes it possible to realize not only linear, convex or concave, but also $S$ (Z)-like dependencies on their values. To solve the problem of parametric synthesis of models of multicriteria TS estimation, the method of comparative identification of a decision maker's preferences is improved on the basis of the procedures for calculating the Chebyshev point and the residual vector. The experimental study of the efficiency of the suggested variant of the method is carried out. Conclusions. The application of the suggested function in additive-multiplicative models of TS multi-factor estimation does not change the methods for selecting their parameters. The suggested improvement of the method of comparative identification of a decision maker's preferences on the basis of the procedures for calculating the Chebyshev point and the residual vector for the parametric synthesis of models of TS multicriteria estimation enables covering all practically important situations of selection described by binary relations of equivalence, strict, and nonstrict preferences. The experimental study of the method confirms the increase in the efficiency of the procedures of parametric synthesis of models built on its basis in comparison with the method of group accounting of arguments on the basis of genetic algorithms. Practical application of the results obtained in the support systems for making multicriteria design and management decisions will improve their accuracy and, on this basis, increase the functional and cost efficiency of modern TS.

Keywords: technological system, design, reengineering, optimization, quality criteria, multicriteria estimation model, utility function, Kolmogorov-Gabor polynomial.

\section{Introduction}

Modern multiproduct manufacturing is characterized by a wide variety of types of raw materials, methods of its processing and the assortment of finished products. The conditions of competition orient it towards all possible reducing the terms of mastering new types of products and improving their quality. In the context of modern methodology, the production process is represented as a technological system (TC) or a set of such systems. The efficiency of technological systems is largely determined by decisions that are made at the stages of their design or reengineering. The processes of TS design, modernization, planning the development or reengineering involve the solution of many interconnected tasks of their structural, topological and parametric optimization. The optimization of production technological systems lies in the fact of selecting the best option from a set of options that satisfy all functional and value constraints according to a variety of quality indicators (quality, cost of production, system performance, equipment loading, and so on) [1-3]. At the same time, one of the priority tasks is the task of developing models for automated multicriteria estimation of variants of building technological systems.

\section{The analysis of the problem current state}

The modern technology of TC optimization involves solving many tasks: selecting system quality indicators (private criteria of optimality); determining the parameters that determine the efficiency of the system; developing a generalized system efficiency criterion; selecting the best option for building a system. The methodology for solving TS optimization problems is based on the theory of multicriteria decision making [4-6]. In addition, a decision maker can select the best decision from the set of efficient ones only in the simplest situations without using formal methods [6]. Additional information about the value of individual formalized properties (private criteria) and their values should be included to automate the procedures for assessing design decisions [7].

The most important task of formalizing the decisionmaking process in the context of TS multicriteria optimization is to determine a metric for ranking alternatives. The utility theory [8] is traditionally used as a methodological basis for developing the metric; according to this theory, the value of utility (values) $P(\lambda, x)$ (where $\lambda$ is the vector of the parameters of the function) can be determined for each alternative variant of TS building $x$ from an admissible set $X$. At the same all $x, y \in X$ :

$$
\begin{gathered}
x \sim y \leftrightarrow P(\lambda, y) \leftrightarrow P(\lambda, x)=P(\lambda, y) \leftrightarrow P(\lambda, x)=P(\lambda, y), \\
x \succ y \leftrightarrow P(\lambda, x)>P(\lambda, y) ; x_{\succ}^{\sim} y \leftrightarrow P(\lambda, x) \geq P(\lambda, y) .
\end{gathered}
$$

As the requirements to TS features are not fully determined as the function of total utility $P(\lambda, x)$, it is suggested to use the fuzzy set adjective "the best variant of building a technological systems" [9]. In this case, the fuzzy set "the best variant of building a technological system"can be presented as a set of ordered pairs:

"the best variant of building a technological system" = 


$$
=\{<x, P(\lambda, x)>\}
$$

where $x \in X$ is a variant of building the system; $P(\lambda, x)$ is the membership degree of the variant $x \in X$ to the fuzzy set "the best variant of building a technological system".

Determining a metric for ranking the variants of TS building $x \in X$ is actually solving the task of identification of a decision maker's preferences, that is solving the tasks of structural and parametric synthesis of the total utility function (TUF) $P(\lambda, x)$. In the general case, this involves selecting a similarity criterion, a set of input signals, structure and parameters of the function $P(\lambda, x)$, assessing its accuracy or adequacy to a decision maker's preferences. When the selected model structure is selected as $P(\lambda, x)$, the task is to determine the best values of its parameters $\lambda=\lambda^{\circ}$.

Depending on the problem situation criteria of identification (similarity of models) are: the minimum of summary (mean, maximum, summary squared) absolute, relative error of estimation of total utility $P(\lambda, x)$, the maximum of preferences force, the midpoint maximum, the maximum of the function of use appropriateness or the minimum of the error of establishing the order of alternatives $x \in X$ [10].

The models of multicriteria assessing and selecting are built on the basis of additive, multiplicative or mixed TUF [7]:

$$
\begin{gathered}
P(\lambda, x)=\sum_{i=1}^{m} \lambda_{i} \xi_{i}(x) ; \\
P(\lambda, x)=\prod_{i=1}^{m}\left[\xi_{i}(x)\right]^{\lambda_{i}} ; \\
P(\lambda, x)=\sum_{i=1}^{m} \lambda_{i} \cdot \xi_{i}(x)+\sum_{i=1}^{m} \sum_{j=i}^{m} \lambda_{i j} \cdot \xi_{i}(x) \cdot \xi_{i}(x)+\ldots,
\end{gathered}
$$

where $P(\lambda, x)$ is the estimation of an alternative utility $x$; $m$ is a number of partial criteria; $\lambda_{i}, \lambda_{i j}$ are weight coefficients of partial criteria $k_{i}(x)$ and their products $\lambda_{i} \geq 0, \lambda_{i j} \geq 0 ; i=\overline{1, m} ; \quad \xi_{i}(x)=\xi_{i}\left[k_{i}(x)\right]$ is a partial criterion utility function (PCUF) $k_{i}(x), i=\overline{1, m}$.

The main drawback of the models of the form (1) is that they do not reflect the objective role of partial criteria and allow practically unlimited compensation of one criterion by others. The drawback of models of the form (2) is that they can compensate for the insufficient value of one particular criterion by the excess of another one. The utility function built on the basis of the KolmogorovGabor polynomial (3) can overcome the drawbacks of the models (1) and (2) [7].

If the vector of parameters $\lambda$ is determined and the type of the function of partial criteria utility $\xi_{i}(x)$, $i=\overline{1, m}$ is known, the task of selecting the best variant of TS building for the models of the form (1) - (3) can be reduced to the task of optimization:

$$
x^{o}=\arg \max _{x \in X} P(\lambda, x) .
$$

The vector of weight coefficients is traditionally determined with the help of the expert method by ranking methods, attributing points, sequential preferences, paired comparisons [5, 6]. The drawbacks of the mentioned methods are the complexity and relatively low accuracy of estimates.

The technique of the comparative identification is used as an alternative to the expert assessment of parameters [11-12]. For structural and parametric identification of the models of the mixed type (3), the method of arguments group accounting (MAGA) on the basis of genetic algorithms is suggested [12-13]. The practical application of this method is limited by its high time complexity and low accuracy of obtained solutions.

The review of the current state of the problem shows that the tasks of parametric or structural and parametric synthesis have been studied so far in one of the types of additive, multiplicative or mixed functions of the total utility $P(\lambda, x)(1)-(3)$ that are built on the basis of nonuniversal utility functions of partial criteria $\xi_{i}(x)$, $i=\overline{1, m}$, using the approximate methods of identification $[6,7$ 10, 12-14].

\section{The research goal and objectives}

The object of the research is technological production systems.

The subject of the research is the process of interactive multi-factor estimation of the variants of building technological production systems.

The goal of the research is to increase the efficiency of the procedures of multicriteria estimation of the features of technological systems at the stages of their design and reengineering using the method of comparative parametric identification of a decision maker's preferences.

The achieve the stated goal, it is necessary:

- to increase the adequacy of the additive multiplicative model of multi-factor estimation of variants of building the TS built on the basis of the KolmogorovGabor polynomial;

- to develop the efficient method of the parametric synthesis of additive multiplicative models of the multifactor estimation and selection of the variants of TS building;

- to conduct the analysis and give recommendations as to the practical application of the suggested method of the parametric synthesis of the models of TS multicriteria estimation.

\section{The research materials}

The task of parametric synthesis of the models of multicriteria estimation of technological systems will be solved using the general utility function $P(\lambda, x)$ built on the basis of the Kolmogorov-Gabor polynomial (3). The general function of partial criteria utility $\xi_{i}(x), i=\overline{1, m}$ will be used as a constituent of the general utility function. 
The general function of partial criteria utility enables implementing linear, convex, concave, $S$ - and $Z$-shaped dependences on the values of partial criteria $k_{i}(x)$, $i=\overline{1, m}$ with the high degree of accuracy[14, 15]:

$$
\xi(x)=\left\{\begin{array}{l}
\bar{a} \cdot\left(\frac{\bar{k}(x)}{\bar{k}_{a}}\right)^{\alpha_{1}}, \quad 0 \leq \bar{k}(x) \leq \bar{k}_{a} ; \\
\bar{a}+(1-\bar{a}) \cdot\left(\frac{\bar{k}(x)-\bar{k}_{a}}{1-\bar{k}_{a}}\right)^{\alpha_{2}}, \bar{k}_{a}<\bar{k}(x) \leq 1, \\
\bar{k}(x)=\frac{k(x)-k^{-}}{k^{+}-k^{-}}, i=\overline{1, m},
\end{array}\right.
$$

where $\bar{k}_{a}, \bar{a}$ are normalized values of coordinates of the point of function sewing, $\quad 0 \leq \bar{k}_{a} \leq 1, \quad 0 \leq € \leq 1$; $\alpha_{1 i}, \alpha_{2 i}$ are the factors that determine the type of the dependence at the starting and final sections of the function; $k(x), k^{+}, k^{-}$are the values of a partial criterion for the variant $x$, the best and the worst values of the criterion $k(x)$.

This function exceeds the known Gaussian function, Harrington function, and logistic function with respect to the accuracy of the approximation of a decision maker's estimations [14].

The essence of the technology of comparative identification of a decision maker's preferences when optimizing TS lies in the following fact. The types of the partial criteria utility function are given as $\xi_{i}(x), i=\overline{1, m}$ (5) and TUF $P(\lambda, x)$ (3), they represent the TS most important features. A decision maker implements the pairs of the variants of TS building from the subsets of the admissible ones which creates in the consciousness of a decision maker some subjective estimations of the utility $P(x)$ and $P(y)$, whose values cannot be measured. Binary relations are developed on the basis of these estimations (the equivalence or preference of variants is justified):

- variant equivalence $R_{E}(X)=\{\langle x, y\rangle: x, y \in X, x \sim y\}$;

- strict preference $R_{S}(X)=\{\langle x, y\rangle: x, y \in X, x \succ y\}$;

- preference-indifference

relation $R_{N}(X)=\left\{\langle x, y\rangle: x, y \in X, x_{\succ}^{\sim} y\right\}$.

Corresponding systems of equations and inequalities are derived:

$$
\begin{aligned}
& P(\lambda, x)=P(\lambda, y), x, y \in R_{E}(X), \\
& P(\lambda, x)>P(\lambda, y), x, y \in R_{S}(X), \\
& P(\lambda, x) \geq P(\lambda, y), x, y \in R_{N}(X),
\end{aligned}
$$

where $\lambda$ is the target vector of TUF parameters.

Therefore, the task of parametric identification of TUF of TS variants is to determine the vector $\lambda=\left[\lambda_{i}\right]_{i=1}^{N}$ (where $N$ is a number of model parameters) that meet the requirements of the derived system of equations and inequalities (7), (8) or (9). In addition, the derived system of equations and inequalities can be incompatible or can have innumerable solutions.

The minimum error in ordering the priority of alternatives and the minimum sum of the squares of estimating the errors of the alternatives utility are selected as the criteria for identifying a decision maker's preferences when solving the task of TS optimization. A number of components of the model (3) is selected on the basis of the required accuracy of ordering a decision maker's preferences, the dimension of the task, and the available computing resources. At the same time, the maximum number of summands is equal $N=C_{m+n}^{n}-1$ (where $\mathrm{m}$ is a number of partial criteria; $\mathrm{n}$ is the polynomial degree).

The following notation is introduced:

$$
\begin{gathered}
\xi_{I}(x) \cdot \xi_{I}(x)=\xi_{m+1}(x), \lambda_{1,1}=\lambda_{m+1}, \xi_{I}(x) \cdot \xi_{2}(x)=\xi_{m+2}(x), \\
\lambda_{1,2}=\lambda_{m+2}, \ldots
\end{gathered}
$$

Taking into account these notations (10) the function (3) can be presented as the additive one (11):

$$
P(\lambda, x)=\sum_{i=1}^{N} \lambda_{i} \xi_{i}(x) \text {. }
$$

The components of the vector $\lambda$ should be estimated basing a decision maker's preferences among the alternatives $x, y \in X^{C}$ (where $X^{C}$ is a subset of the Pareto-efficient alternatives). The pairs of alternatives should belong to a subset of the Pareto-efficient ones, which is caused by the fact that considering dominating alternatives from the subset of the agreement $X^{S}=X \backslash X^{C}$ while developing the binary relations of strict preference $R_{S}(X)$ and preference-indifference relation $R_{N}(X)$ does not contain useful information, that is $x \succ z \quad \forall x \in X^{C}$ and $\forall z \in X^{S}$. This is due to the fact that strict preference and preference-indifference relation for dominating alternatives are performed under any values of weight coefficients $\lambda_{i}, i=\overline{1, N}$.

For equivalence relation $R_{E}(X)$ according to the model (11) the system of equations including $\mathrm{nE}$ equation is derived from the condition $P(x)=P(y)$, $(x, y) \in R_{E}(X)$ :

$$
\begin{gathered}
\eta_{j}(\lambda) \equiv \sum_{i=1}^{N} \lambda_{i} \xi_{i}(x)=\sum_{i=1}^{N} \lambda_{i} \xi_{i}(y), \quad<x, y>\in R_{E}(X), \\
j=\overline{1, n_{E}},
\end{gathered}
$$

As well as the equation for normalizing the vector

$$
\eta_{n_{E}+1}(\lambda) \equiv \sum_{i=1}^{N} \lambda_{i}=1, \quad \lambda_{i} \geq 0, \quad i=\overline{1, N},
$$

where $n_{E}=\operatorname{Card} R_{E}(X)$ is the cardinality of the equivalence relation $R_{E}(X)$. 
For strict preference $R_{S}(X)$ preference-indifference relation $R_{N}(X)$ the systems of non-linear inequalities and normalizing conditions are obtained:

$$
\begin{gathered}
\eta_{j}(\lambda) \equiv \sum_{i=1}^{N} \lambda_{i} \xi_{i}(x)>\sum_{i=1}^{N} \lambda_{i} \xi_{i}(y),<x, y>\in R_{S}(X), \\
j=\overline{l, n_{S}}, \\
\eta_{n_{S}+1}(\lambda) \equiv \sum_{i=1}^{N} \lambda_{i}=1, \quad \lambda_{i} \geq 0, \quad i=\overline{1, N} ; \\
\eta_{j}(\lambda) \equiv \sum_{i=1}^{N} \lambda_{i} \xi_{i}(x) \geq \sum_{i=1}^{N} \lambda_{i} \xi_{i}(y), \quad<x, y>\in R_{N}(X), \\
j=\overline{l, n_{N}}, \\
\eta_{n_{N}+1}(\lambda) \equiv \sum_{i=1}^{N} \lambda_{i}=1, \quad \lambda_{i} \geq 0, \quad i=\overline{1, N},
\end{gathered}
$$

where $\quad n_{S}=\operatorname{Card} R_{S}(X), \quad n_{N}=\operatorname{Card} R_{N}(X)$ cardinalities of relations $R_{S}(X)$ and $R_{N}(X)$.

The obtained systems of equations and inequalities (12) - (14) are homogeneous and specify numerous planes that cross the zero point of the coordinate system. Their second parts as normalizing conditions $\sum \lambda_{i}=1, \quad \lambda_{i} \geq 0$ determine secant lines. Thus, Haar condition is met, and systems (12) - (14) are inconsistent в in general.

One of the methods of solving similar systems is searching the Chebyshev point [7], which enables reducing original tasks to the tasks of linear programming $[11,16]$. If the additional variable $\lambda_{N+1}$ is added to the system of equations (12), the set of constraints $\left|\eta_{j}(\lambda)\right| \leq \lambda_{N+1}, j=\overline{1, n_{E}}$ can be created to get the equivalence relation $R_{E}(X)$. It is as follows:

$$
\begin{gathered}
-\eta_{j}(\lambda)+\lambda_{N+1} \geq 0, \quad \eta_{j}(\lambda)+\lambda_{N+1} \geq 0, \quad j=\overline{1, n_{E}}, \\
\eta_{n_{E}+1}(\lambda) \equiv \sum_{i=1}^{N} \lambda_{i}=1, \quad \lambda_{i} \geq 0, \quad i=\overline{l, N} .
\end{gathered}
$$

Minimizing $\lambda_{N+1} \rightarrow \min$ in the context of constraints (15) is a task of linear programming and enables obtaining the Chebyshev point of the system (12). In this case the Chebyshev point $\lambda^{o}$ has geometrically least deviation in modulus $|r|$ from the whole set of equation planes (12)

$$
|r|=\min _{\lambda} \max _{j}\left|\eta_{j}(\lambda)\right|=\max _{j}\left|\eta_{j}\left(\lambda^{o}\right)\right| \text {. }
$$

The additional variable $\lambda_{N+1}$ is introduced to the constraints (13) for the relation $R_{S}(X)$, the conditions $\eta_{j}(\lambda) \leq \lambda_{N+1}, \quad j=\overline{l, n_{S}}$ should be performed. Then, searching the Chebyshev point of the system of inequalities (13) is reduced to a task of linear programming:

$$
\begin{gathered}
\lambda_{N+1} \rightarrow \min ;-\eta_{j}(\lambda)+\lambda_{N+1} \geq 0, \quad j=\overline{1, n_{S}}, \\
\eta_{n_{S}+1}(\lambda) \equiv \sum_{i=1}^{N} \lambda_{i}=1, \quad \lambda_{i} \geq 0, \quad i=\overline{1, N} .
\end{gathered}
$$

If the system of inequalities (13) is consistent, $r=\min _{\lambda} \max _{j} \eta_{j}(\lambda) \leq 0$, and the obtained solution $\lambda^{o}$ will be highly sustainable to probable shifts of constraint planes. If the system (13) is inconsistent, $r>0$, and the Chebyshev approximation is obtained, which is the value of minimal deviation for solving the target systems. In this case, for the system of preferences, which is described by the binary relation $R_{S}(X)$, there is not a single vector of weight coefficients of partial criteria $\lambda$ that meet the requirements of (13).

Searching the Chebyshev solution (approximation) of the system of linear inequalities and constraints for preference-indifference relation $R_{N}(X)$ is reduced to a task of linear programming in the same way (14).

The drawback of solutions in the form of the Chebyshev point is their orientation only to the extreme constraints and to the minimization the maximum deviation of the obtained point from the planes of deviations $\eta_{j}(\lambda)$. Generic solutions of the systems (12) - (14) are suggested for using as an alternative to the solutions in the form of the Chebyshev point. that take into account the removal (or deviation) from the whole set of constraints [11]. The vector can be used as the solution of the system (12) for the relation of equivalence $R_{E}(X)$

$$
\lambda^{o}=\arg \underset{\lambda}{\min }\|A \lambda-b\|,
$$

where $\|A \lambda-b\|$ is the norm of the residual vector; $A=\left[a_{i j}\right]$ is the matrix of coefficients for the system (12), the elements of which are $a_{j i}=\left[\xi_{i}(y)-\xi_{i}(x)\right], \quad j=\overline{1, n_{E}}, \quad i=\overline{1, m} ; \quad j$ is the pair number $\langle x, y\rangle$ in the ratio of $R_{E}(X)$; $a_{n_{E}+1, i}=1, i=\overline{1, m} ; \quad b=[0,0, \ldots, 1]^{T}$.

\section{The research results}

The suggested method has shown its efficiency and effectiveness in solving test tasks. The results of solving the tasks from $[10,12,13]$ were used for comparison.

In [13], a special case of the function (3) was used as a model to estimate the variants according to four particular criteria

$$
\begin{aligned}
& P(\lambda, x)=\sum_{i=1}^{4} \lambda_{i} \cdot \xi_{i}(x)+\lambda_{5} \cdot \xi_{1}^{2}(x)+ \\
& +\lambda_{6} \cdot \xi_{2}^{2}(x)+\lambda_{7} \cdot \xi_{3}(x) \cdot \xi_{4}(x)
\end{aligned}
$$

With weight coefficients $\mathrm{a}=[0.33 ; 0.12 ; 0.15 ; 0.08$; $0.1 ; 0.15 ; 0.07]$. The values of TUF $P(\lambda, x)$, obtained on the basis of the model (19), determine the following order at a set of alternatives $x_{l} \in X, l=\overline{1,12}$ (table 1): 
$x_{6} \succ x_{10} \succ x_{1} \succ x_{9} \succ x_{7} \succ x_{4} \succ x_{5} \succ x_{11} \succ x_{12} \succ x_{2} \succ x_{8} \succ x_{3} .(20)$

After the following notations had been introduced:

$$
\begin{gathered}
\xi_{1}(x) \cdot \xi_{1}(x)=\xi_{5}(x), \xi_{1}(x) \cdot \xi_{2}(x)=\xi_{6}(x), \\
\xi_{3}(x) \cdot \xi_{4}(x)=\xi_{7}(x),
\end{gathered}
$$

the model (19) was presented in the additive form:

$$
P(\lambda, x)=\sum_{i=1}^{7} \lambda_{i} \xi_{i}(x) .
$$

To estimate the method efficiency, many tasks of parametric identification of a decision maker's preferences in the form of (3) were solved for the conditions of strict preferences and equivalence: task 1 is to determine the best parameters of the model (19) that fulfil the condition $P\left(\lambda, x_{6}\right)>P\left(\lambda, x_{l}\right)$, $\forall l=\overline{1,12}, l \neq 6$; task 2 is to determine the best values of the parameters of the model (19) that lays down the order (20); task 3 is to determine the best values of the parameters of the model (19) that fulfil the conditions $P\left(\lambda, x_{6}\right)=P\left(\lambda, x_{l}\right), \forall l=\overline{1,12}$; task 4 is to determine the type and parameters of the model of the second degree (3) on the basis of the fact of selecting a decision maker's variant $x^{o}=x_{6}$, that is the one which fulfils the condition $P\left(\lambda, x_{6}\right)>P\left(\lambda, x_{l}\right), \forall l=\overline{1,12}, l \neq 6$; task 5 is to determine the type and parameters of the model of the second degree (3) that lays down the order (20); task 6 is to determine the type and parameters of the model of the second degree (3) that fulfils the conditions $P\left(\lambda, x_{6}\right)=P\left(\lambda, x_{l}\right), \forall l=\overline{1,12}$.

Table 1. The characteristics of the variants of TS building

\begin{tabular}{|c|c|c|c|c|c|}
\hline$x$ & $\xi_{1}(x)$ & $\xi_{2}(x)$ & $\xi_{3}(x)$ & $\xi_{4}(x)$ & $P(\lambda, x)$ \\
\hline$x_{1}$ & 0,87 & 0,11 & 0,55 & 0,12 & 0,4745 \\
\hline$x_{2}$ & 0,42 & 0,37 & 1,0 & 0,0 & 0,3712 \\
\hline$x_{3}$ & 0,11 & 0,66 & 0,34 & 0,82 & 0,3182 \\
\hline$x_{4}$ & 0,74 & 0,24 & 0,19 & 0,52 & 0,4134 \\
\hline$x_{5}$ & 0,0 & 1,00 & 0,64 & 0,25 & 0,3972 \\
\hline$x_{6}$ & 1,0 & 0,0 & 0,44 & 0,36 & 0,5359 \\
\hline$x_{7}$ & 0,40 & 0,80 & 0,59 & 0,05 & 0,4346 \\
\hline$x_{8}$ & 0,49 & 0,46 & 0,0 & 1,0 & 0,3527 \\
\hline$x_{9}$ & 0,64 & 0,42 & 0,32 & 0,78 & 0,4569 \\
\hline$x_{10}$ & 0,92 & 0,08 & 0,38 & 0,25 & 0,4825 \\
\hline$x_{11}$ & 0,18 & 0,60 & 0,64 & 0,85 & 0,3907 \\
\hline$x_{12}$ & 0,25 & 0,55 & 1,00 & 0,18 & 0,3771 \\
\hline
\end{tabular}

All the mentioned tasks are incorrect according to Hadamard: tasks 1, 2, 4 and 5 have the infinite set of solutions; tasks 3 and 6 do not have a single solution. Regularizing the tasks of searching the solutions of the system of equations and inequalities (12)-(13) in the form of $(17)-(18)$ enables obtaining unambiguous solutions.

The obtained solutions of tasks 1, 2, 4, 5 enable restoring the complete initial order of a decision maker's preferences with the inaccuracy of reference values by $63,2-87,3 \%$ less than while using the method of the group accounting of arguments.

The residual vector (18) was minimized for tasks 3 and 6 , which enables obtaining the parameters of the models $\lambda=\left\{\lambda_{i}\right\} ; \quad \sum_{i=1}^{N} \lambda_{i}=1, \quad \lambda_{i} \geq 0, \quad i=\overline{1, N} \quad$ that equalize the values of all variants $P\left(\lambda, x_{6}\right) \approx P\left(\lambda, x_{l}\right)$, $\forall l=\overline{l, 12}$ to the fullest extent. In addition, the maximum deviation from the equality of the values of variants utility was 0,2177 for task 3 , and 0,1826 for task 6 .

\section{Conclusions}

The approach of the comparative identification of the vectors of preferences for models of multivariate estimating and selecting solutions based on the Kolmogorov-Gabor polynomial was further developed as a result of the analysis of the problem of estimating the properties of technological systems in the process of their optimization.

In order to increase the adequacy of multi-factor estimation models, it is suggested to use the utility function of partial criteria, which enables implementing not only linear, convex or concave, but also $S(Z)$-shaped dependences on their values. Its use makes it possible to increase the accuracy of expert approximate estimates significantly compared to the models built on the basis of Gaussian functions, Harrington and logistic function. Moreover, the application of the suggested function in available models of multi-factor estimation does not change the methods of selecting their parameters.

Improving the method of comparative identification is suggested on the basis of the procedures for calculating the Chebyshev point and the residual vector is suggested for the parametric synthesis of models of multicriteria 
estimation of technological systems. This enables covering all practically important situations of a decision maker's selection that are described by the binary equivalence relations, strict preferences, preferenceindifference relations, and increasing the efficiency of the synthesis procedures in comparison with the method of group accounting of arguments based on genetic algorithms.

The practical application of the results obtained in the systems that support making multicriteria design and management decisions will increase their accuracy and, on this basis, increase the functional and cost efficiency of modern technological systems. Developing efficient mathematical models, methods, and information technologies of integrating decision support means into the technology of design, adaptation and reengineering of technological systems can be the directions of further research in this area.

\section{References}

1. Ilyushina, S. V. (2014), "Methods of optimization of technological processes" [Metody optimizatsii tekhnologicheskikh protsessov]. Vestnik Kazanskogo tekhnologicheskogo universiteta. Vol. 17. No. 8. P. 323-327.

2. Dovbysh, A. S., Berest, O. B. (2014), "Three-alternative learning system for decision support for the automation of the technological process" [Trokhal'ternativnaya obuchayushchayasya sistema podderzhki prinyatiya resheniy dlya avtomatizatsii tekhnologicheskogo protsessa]. Vestnik Tomskogo gosudarstvennogo universiteta. Upravleniye, vychislitel'naya tekhnika i informatika. No. 4 (29). P. 31-40.

3. Frolov, V. V. (2012), "Method of combinatorial-optimization design of technological machining systems " [Metod kombinatornooptimizatsionnogo proyektirovaniya tekhnologicheskikh sistem mekhanicheskoy obrabotki]. Otkrytyye informatsionnyye $i$ komp'yuternyye integrirovannyye tekhnologii. No. 54. P. 125-131.

4. Greco, S., Ehrgott, M., Figueira, J. R. (2016), Multiple Criteria Decision Analysis - State of the Art Surveys. New York: Springer. $1346 \mathrm{p}$.

5. Kaliszewski, I., Kiczkowiak, T., Miroforidis, J. (2016), "Mechanical design, Multiple Criteria Decision Making and Pareto optimality gap". Engineering Computations. Vol. 33 (3). P. 876-895.

6. Kryuchkovskiy, V. V., Petrov, E. G., Sokolova, N. A., Khodakov, V. Ye. (2013), Introduction to the normative theory of decision-making [Vvedeniye v normativnuyu teoriyu prinyatiya resheniy]. Kherson: Grin' D. S. 284 p.

7. Ovezgel'dyyev, O. A., Petrov, E. G., Petrov, K. E. (2002), Synthesis and identification of models of multifactor estimation and optimization [Sintez i identifikatsiya modeley mnogofaktornogo otsenivaniya i optimizatsii]. Kyiv: Naukova dumka. $161 \mathrm{p}$.

8. Fishbern, P., edited by Moudera Dzh., Elmagrabi S.: Translated from English (1981), "Theory of Utility. Research of operations: V 2 t" [Teoriya poleznosti. Issledovaniye operatsiy: V 2 t.]. Metodologicheskiye osnovy i matematicheskiye metody. Moscow: Mir. Vol. 1. P. 448-480.

9. Raskin, J. G., Seraya, O. V. (2008), Fuzzy Mathematics. Fundamentals of the theory. Applications [Nechetkaya matematika. Osnovy teorii. Prilozheniya]. Kharkiv: Parus.352 p.

10. Petrov, E. G., Shilo, N. S. (2003), "Methodology for assessing the adequacy of models of point identification of individual preferences of decision-makers" [Metodika otsenki adekvatnosti modeley tochechnoy identifikatsii individual'nykh predpochteniy LPR]. Radioelektronika i informatika. No. 2. P. 97-103.

11. Beskorovainyi, V V, Trofimenko, I V (2006), "Structural-parametric identification of models of multifactor estimation" [Strukturno-parametrychna identyfikatsiya modeley bahatofaktornoho otsinyuvannya]. Systems of Arms and Military Equipment. No. 3 (7). P. 56-59.

12. Petrov, K. E., Kryuchkovskiy, V. V. (2009), Comparative structural-parametric identification of models of scalar multivariate estimation: monograph [Komparatornaya strukturno-parametricheskaya identifikatsiya modeley skalyarnogo mnogofaktornogo otsenivaniya: monografiya]. Kherson: Oldi-plyus. 294 p.

13. Petrov, E. G., Bulavin, D. A., Petrov, K. E. (2004), "Solution of the problem of structural-parametric identification of the model of individual multifactor estimation by the method of group accounting of arguments" [Resheniye zadachi strukturnoparametricheskoy identifikatsii modeli individual'nogo mnogofaktornogo otsenivaniya metodom gruppovogo ucheta argumentov]. Avtomatizirovannyye sistemy upravleniya i pribory avtomatiki. Issue 129. P. 4-13.

14. Beskorovainyi, V. V., Soboleva, E. V. (2010), "Identification of the partial utility of multifactorial alternatives using S-shaped functions" [Identifikatsiya chastnoy poleznosti mnogofaktornykh al'ternativ s pomoshch'yu S-obraznykh funktsiy]. Bionika intellekta. No. 1. P. 50-54.

15. Petrov, E. G., Beskorovainyi, V. V., Pisklakova, V.P. (1997), "Formation of utility functions of particular criteria in multicriterion estimation problems" [Formirovaniye funktsiy poleznosti chastnykh kriteriyev v zadachakh mnogokriterial'nogo otsenivaniya]. Radioelektronika i informatika. No. 1. P. 71-73.

16. Beskorovainyi, V. V., Trofimenko, I. V. (2005), "Parametric identification of additive-multiplicative models of multifactor estimation" [Parametricheskaya identifikatsiya additivno-mul'tiplikativnykh modeley mnogofaktornogo otsenivaniya]. Radioelectronics and Informatics. No. 4. P. 41-46.

Receive 15.09.2017

Відомості про авторів / Сведения об авторах / About the Authors

Безкоровайний Володимир Валентинович - доктор технічних наук, професор, Харківський національний університет радіоелектроніки, професор кафедри системотехніки, м. Харків, Україна; е-mail: vladimir.beskorovainyi@nure.ua, ORCID: 0000-0001-7930-3984.

Бескоровайный Владимир Валентинович - доктор технических наук, профессор, Харьковский национальный университет радиоэлектроники, профессор кафедры системотехники, г. Харьков, Украина; e-mail: vladimir.beskorovainyi@ nure.ua, ORCID: 0000-0001-7930-3984. 
Beskorovainyi Vladimir - Doctor of Sciences (Engineering), Professor, Kharkiv National University of Radioelectronics, Professor of the Department of System Engineering, Kharkiv, Ukraine; e-mail: vladimir.beskorovainyi@nure.ua, ORCID: 0000-0001-7930-3984.

\section{ПАРАМЕТРИЧНИЙ СИНТЕЗ МОДЕЛЕЙ БАГАТОКРИТЕРІАЛЬНОГО ОЦІНЮВАННЯ ТЕХНОЛОГІЧНИХ СИСТЕМ}

Предметом дослідження в статті є проблема багатокритеріальної оцінки властивостей технологічних систем (ТC) у процесі їхної структурно-параметричної оптимізації. Метою дослідження $є$ підвищення ефективності процедур багатокритеріальної оцінки властивостей Т3 на етапах їх проектування та реінжинірингу із використанням технології компараторної параметричної ідентифікації переваг особи, що приймає рішення (ОПР). Задачі: підвищити адекватність адитивномультиплікативної моделі багатофакторного оцінювання варіантів побудови ТС, створеної на основі полінома КолмогороваГабора; розробити ефективний метод параметричного синтезу адитивно-мультиплікативних моделей багатофакторного оцінювання та вибору варіантів побудови ТС на основі переваг ОПР; провести аналіз і дати рекомендації щодо практичного використання запропонованого методу параметричного синтезу моделей багатокритеріального оцінювання ТС. Використовувані методи: системний аналіз, теорія прийняття рішень, теорія ідентифікації, методи багатокритеріальної оптимізації. Отримані такі результати. Для підвищення адекватності моделей багатофакторного оцінювання ТС запропоновано використовувати функцію корисності часткових критеріїв, що дозволяє реалізувати не тільки лінійні, опуклі або увігнуті, але i S (Z)-образні залежності від їх значень. Для розв'язання задачі параметричного синтезу моделей багатокритеріального оцінювання ТС удосконалений метод компараторної ідентифікації переваг ОПР на основі процедур обчислення чебишовської точки i вектора нев'язки. Проведено експериментальне дослідження ефективності запропонованого варіанту методу. Висновки. Застосування запропонованої функції в адитивно-мультиплікативних моделях багатофакторного оцінювання ТЗ не вносить змін до методів вибору їхніх параметрів. Запропоноване удосконалення методу компараторної ідентифікації переваг ОПР на основі процедур обчислення чебишовської точки та вектора нев’язки для параметричного синтезу моделей багатокритеріального оцінювання ТЗ дозволяє охопити всі практично важливі ситуації вибору, що подаються бінарними відношеннями еквівалентності, строгої та нестрогої переваг. Експериментальне дослідження методу підтверджує підвищення ефективності побудованих на його основі процедур параметричного синтезу моделей у порівнянні з методом групового обліку аргументів на основі генетичних алгоритмів. Практичне застосування отриманих результатів у системах підтримки прийняття багатокритеріальних проектних і управлінських рішень дозволить підвищити їх точність і на цій основі підвищити функціонально-вартісну ефективність сучасних ТЗ.

Ключові слова технологічна система, проектування, реінжиніринг, оптимізація, критерії якості, модель багатокритеріального оцінювання, функція корисності, поліном Колмогорова-Габора.

\section{ПАРАМЕТРИЧЕСКИЙ СИНТЕЗ МОДЕЛЕЙ МНОГОКРИТЕРИАЛЬНОГО ОЦЕНИВАНИЯ ТЕХНОЛОГИЧЕСКИХ}

Предметом изучения в статье является проблема многокритериальной оценки свойств технологических систем (ТС) в процессе их структурно-параметрической оптимизации. Целью исследования является повышение эффективности процедур многокритериальной оценки свойств ТС на этапах их проектирования и реинжиниринга с использованием технологии компараторной параметрической идентификации предпочтений лица, принимающего решения (ЛПР). Задачи: повысить адекватность аддитивно-мультипликативной модели многофакторного оценивания вариантов построения ТС, построенной на основе полинома Колмогорова-Габора; разработать эффективный метод параметрического синтеза аддитивномультипликативных моделей многофакторного оценивания и выбора вариантов построения ТС на основе предпочтений ЛПР; провести анализ и дать рекомендации по практическому использованию предложенного метода параметрического синтеза моделей многокритериального оценивания ТС. Используемые методы: системный анализ, теория принятия решений, теория идентификации, методы многокритериальной оптимизации. Получены следующие результаты. Для повышения адекватности моделей многофакторного оценивания ТС предложено использовать функцию полезности частных критериев, позволяющую реализовать не только линейные, выпуклые или вогнутые, но и $\mathrm{S}(\mathrm{Z})$-образные зависимости от их значений. Для решения задачи параметрического синтеза моделей многокритериального оценивания ТС усовершенствован метод компараторной идентификации предпочтений ЛПР на основе процедур вычисления чебышевской точки и вектора невязки. Проведено экспериментальное исследование эффективности предложенного варианта метода. Выводы. Применение предложенной функции в аддитивно-мультипликативных моделях многофакторного оценивания ТС не вносит изменений в методы выбора их параметров. Предложенное усовершенствование метода компараторной идентификации предпочтений ЛПР на основе процедур вычисления чебышевской точки и вектора невязки для параметрического синтеза моделей многокритериального оценивания ТС позволяет охватить все практически важные ситуации выбора, описываемые бинарными отношениями эквивалентности, строгого, нестрогого предпочтений. Экспериментальное исследование метода подтверждает повышение эффективности построенных на его основе процедур параметрического синтеза моделей по сравнению с методом группового учета аргументов на основе генетических алгоритмов. Практическое применение полученных результатов в системах поддержки принятия многокритериальных проектных и управленческих решений позволит повысить их точность и на этой основе повысить функционально-стоимостную эффективность современных ТС.

Ключевые слова: технологическая система, проектирование, реинжиниринг, оптимизация, критерии качества, модель многокритериального оценивания, функция полезности, полином Колмогорова-Габора 